${ }^{18}$ RAINE, W. 1896. Raine bets. Nidologist $4: 11$.

${ }^{9}$ RAINE, W. 1896. An old letter. Nidologist $4: 23$

${ }^{20}$ RAINE, W. 1896. Raine's latest. Nidologist $4: 25$.

${ }^{21}$ RAINE, W. Discovery of the eggs of Solitary Sandpiper. Ottawa Naturalist 18:135138.

${ }^{22}$ RAINE, W. 1904. Discovery of the eggs of Solitary Sandpiper. Oologist 21:164168.

${ }^{23}$ REED, C. A. 1904. North American Birds Eggs. New York: Doubleday, Page. 356 pp.

${ }^{24}$ RIPPON, E. P. From E.P. Rippon. Nidologist 4:24-25.
${ }^{25}$ SHUFELDT, R. W. 1896. Raineism. Nidiologist 3:146-148.

${ }^{26}$ SHUFELDT, R. W. 1896. Raineism - a point in explanation. Nidologist 4:25

${ }^{27}$ TAYLOR, H. R. 1895. "Sets" from "singles" Nidiologist 2:129.

${ }^{28}$ (TAYLOR, H. R.). 1896. "Giving the devil his due" Nidologist 4:27.

${ }^{29}$ (VANDERCOCK, O. B.) 1917. My set of nine Barred Owl's eggs. Oologist 34:3233.

${ }^{30}$ WALKINSHAW, L. H. 1949. The Sandhill Cranes. Cranbrook Institute of Science, Bull. 29. 202 pp.

${ }^{31}$ WALKINSHAW, L. H. 1965. A new Sandhill Crane from central Canada. Can. FieldNat. 79:181-184.

\title{
BLACK SCOTER AT INDIAN HEAD, SASKATCHEWAN
}

FRED W. LAHRMAN, 7 - 3941 Retallack Street, Regina, Saskatchewan, S4S 3C1 and LORNE SCOTT, P.O. Box 995, Indian Head, Saskatchewan. SOG 2K0

On 11 November 1980 while observing waterfowl on Deep Lake, 7 mi. south of Indian Head, Lorne Scott and I saw an all black diving duck fly low over the water and alight about 450 yards away. With the aid of a $20 \mathrm{X}$ spotting scope we were able to identify it as a Black Scotter. It was in the all black plumage of the adult male but the yellow knob at the base of the bill, while clearly evident, did not have the full brilliant yellow of the male which was seen on Wascana Lake. ${ }^{2}$ On the following day I saw the bird again in the same area but at much closer range. I believe that this is the first record of the species for the Qu'Appelle area covered by "Birds of the Qu'Appelle 1857-1979."'

Other birds observed on the lake at this late date were 125 Whistling Swan, 300 Canada Goose, 3 White-fronted
Goose, 2 Lesser Snow Goose, 1 Black Duck, 25 Northern Shoveler, 1 Redhead, 1 Canvasback, 100+ Lesser Scaup, 75 Common Goldeneye, 50 Bufflehead, 1 White-winged Scoter, 28 Hooded Merganser and 10 Common Merganser. Other late dates were 1 Turkey Vulture 3 November and 100 Sandhill Crane 15 November observed near Indian Head by Lorne Scott. On 23 November he also saw 2 Lesser Snow and 3 White-fronted Geese at Deep Lake.

'CALLIN, E.M. 1980. Birds of the Qu'Appelle, 1857-1979. Sask. Nat. Hist. Soc. Spec. Publ. 13, Regina, Saskatchewan.

${ }^{2}$ KREBA, R. 1980. A black day at Wascana Marsh, Regina. Blue Jay 38(2):120121. 